\title{
Production of Recombinant Denileukin Diftitox: Assessment in the Lab-scale Bioreactor
}

\author{
Seyed Morteza Robatjazi ${ }^{1}$ (D), Sanaz Mahboudi ${ }^{1}$, Mehdi Zeinoddini $^{* *}$ (D)
}

1. Department of Bioscience and Biotechnology, Faculty of Chemistry and Chemical Engineering, Malek Ashtar University of Technology, Iran.

\begin{tabular}{l|l}
$\begin{array}{c}\text { Use your devic to scan } \\
\text { and read the article online }\end{array}$ \\
scale Bioreactor. Research in Molecular Medicine. 2019; 7(3):21-28. https://doi.org/10.32598/rmm.7.3.21 \\
doi: $:$ https://doi.org/10.32598/rmm.7.3.21
\end{tabular}

\section{(i) (5)}

Article Type:

Research Paper

Article info:

Received: 17 May 2019

Revised: 8 June 2019

Accepted: 30 jun 2019

Keywords:

Immunotoxin, DT389-

IL2, Fermentation,

Bioreactor

\begin{abstract}
A B S T RA C T
Background: Denileukin diftitox is a recombinant immunotoxin composed of truncated diphtheria toxin fused to human interleukin 2 (DT389-IL2). It is a candidate for protein therapy of lymphoma. This work aims to investigate DT389-IL2 production using a recombinant strain of Escherichia coli in the lab-scale bioreactor.

Materials and Methods: First, the effect of chemical composition in culture medium (the complex and defined) was investigated in DT389-IL2 expression in E.coli BL21 (DE3) containing pET-IDZ plasmid in shack flask and lab-bioreactor culture. To enrich the carbon source, we added glucose 6-8 $\mathrm{g} / \mathrm{L}$ to the complex culture medium. The composition of the defined medium was enriched by adding amino acids (valine, 0.0502; phenylalanine, 0.0132; lysine, 0.0184; aspartic acid, 0.016; and serine $0.0251 \mathrm{~g} / \mathrm{L}$ ). The growth cell was measured by the optical density method and the expression yield was investigated by SDS-PAGE.

Results: The maximum growth rate was determined in a modified complex culture medium containing glucose $(6 \mathrm{~g} / \mathrm{L})$. The bacteria growth in the medium was achieved to the optical density of 5.5 in the shack flask culture, and under the same condition, the optical density of medium increased to 13 in the bioreactor. Adding amino acids to the defined medium significantly enhanced cell growth and expression of proteins. Also, the optical densities of 2.95 and 6.1 were achieved in the shack-flask and bioreactor culture, respectively. The specific growth rates of bacteria in the complex medium and the defined medium were determined as 0.89 and $0.47 \mathrm{~h}^{-1}$, respectively.

Conclusion: Adding glucose (carbon source) to the complex medium and elemental enrichment by adding amino acids increased biomass production. The growth cell rate in the bioreactor through suitable control of the environmental conditions and proper mixing was higher compared with the shack-flask culture.
\end{abstract}

\section{Introduction}

ancer is one of the top 10 leading causes of death in most countries, and it is the third leading cause of death in Iran. Therefore, the treatment and prevention of cancer are very important. The direct and smart toxin therapy of tumor cells is a novel and potential strategy for cancer therapy $[1,2]$. Today,

\section{* Corresponding Author:}

Mehdi Zeinoddini, PhD.

Address: Department of Bioscience and Biotechnology, Faculty of Chemistry and Chemical Engineering, Malek Ashtar University of Technology, Iran. Phone: +98 (21) 22974604

E-mail: zeinoddini52@mut.ac.ir 
pharmaceutical companies are trying to discover and develop new anticancer agents. Moreover, recent advances in molecular biology and cancer treatment have led researchers to move toward targeted anticancer drugs $[3,4]$.

The cell-surface antigens or receptors on the tumor cells, expressed as cancer biomarkers, are the best targets for designing new methods of cancer therapy. These methods have been developed over the past two decades. Cancer therapy with targeted toxins is a novel and excellent technique. In this method, the specific drugs are designed to interfere with certain target proteins and exert an inhibition effect on tumor cells. Effective immune therapies such as ligand-targeted therapy and cytokine/ antibody therapy are used to treat cancer. Ligand-targeted treatment is an appropriate way to eliminate the toxicity of anti-cancer drugs in the healthy parts of the patient's body [5-8]. The reaction of monoclonal antibodies with specific antigens creates an inclination to use toxins for removing cancerous cells. The herbal protein and bacterial toxins are potential toxic factors in nature. By attaching these toxins to monoclonal antibodies, new smart proteins, called immunotoxins, are created to remove tumor cells [8-12].

Denileukin diftitox (trade name Ontak ${ }^{\circledR}, \mathrm{DT}_{389} \mathrm{IL} 2$ ) is an artificial protein inspired by native diphtheria toxin and consists of 521-amino acids with three domains and the molecular weight of $58 \mathrm{kDa}$. This targeted toxin is involved truncated diphtheria toxin (Met1-Thr387), genetically fused to the amino acid sequence of human interleukin-2 $\left(\mathrm{Ala}_{1}-\mathrm{Thr}_{133}\right)$. This smart drug is the first recombinant commercial immunotoxin that was approved by the FDA for Cutaneous T Cell Lymphoma (CTCL) treatment in 1999 [13-16].

Various organisms and expressive systems produce recombinant proteins, but Escherichia coli is one of the most common hosts being used to create these proteins due to its rapid proliferation, proper accessible systems for gene manipulation, recognizable genetic structure, physiology, cellular structure, and metabolic routes compared with the other organisms. Also, the bacteria can be cultivated by fermentation methods and in different conditions. Thus, researchers attempted to produce recombinant proteins in E. coli (as the host of recombinant products) to create the required product in a shorter time with the lowest cost $[17,18]$. For mass production of recombinant protein in E. coli, a culture medium rich in nutrients is required. Generally, the cell medium is chosen from a specific culture for cultivation because its nutrients can be controlled in the culture medium.
The complex media like peptone and yeast can be different in the composition and the quality of fermentation. Therefore, sometimes, a specific media with one or some amino acids is required to enhance forming more cells and higher yield of recombinant protein $[19,20]$. The ability of recombinant strain for biomass production depends on two factors of the density of cells and production yield. Optimization of medium culture composition, type of cultivation system, and improving environmental conditions are among the methods used to increase efficiency. In our previous studies, $\mathrm{DT}_{389}$ IL2 was produced in the scale of shake-flask through optimizing the culture medium and its effective parameters [21, 22].

In the present work, and to produce $\mathrm{DT}_{389} \mathrm{IL} 2$ in the bioreactor, several effective parameters on cell growth must be examined. The chemical composition of the culture medium is one of the most important parameters. In this situation, the amount of nutrients in the medium is decisive for the amount of biomass production. In defined mediums, adding amino acids into the cell culture medium increases cell mass production, and accordingly, the amount of target protein expression. Therefore, this work aimed to investigate and assess the culture medium composition effect on the production of denileukin diftitox using recombinant E.coli in the lab-scale bioreactor.

\section{Materials and Methods}

\section{Strain and chemicals}

In this study, E. coli BL21 (DE3) recombinant strain containing $\mathrm{pET}-\mathrm{IDZ}$ produced from previous work was used $[23,24]$. Tryptone Glucose Yeast Extract and the other components of complex and defined medium were purchased from Merck Company. All the materials used in this study were of high purity and were purchased from Sigma-Aldrich, Fluka, and Merck companies.

\section{Growth condition in the shake-flask}

The complex culture medium consisted of glucose, 6-12 g/L; $\mathrm{K}_{2} \mathrm{HPO}_{4}, 12.5 \mathrm{~g} / \mathrm{L} ; \mathrm{KH}_{2} \mathrm{PO}_{4}, 2.3 \mathrm{~g} / \mathrm{L}$; yeast extract, $20 \mathrm{~g} / \mathrm{L}$; and tryptone, $10 \mathrm{~g} / \mathrm{L}$. The defined culture medium consisted of glucose, $8 \mathrm{~g} / \mathrm{L} ; \mathrm{K}_{2} \mathrm{HPO}_{4}, 15$ $\mathrm{g} / \mathrm{L} ; \mathrm{KH}_{2} \mathrm{PO}_{4}, 7.5 \mathrm{~g} / \mathrm{L}$; citric acid, $2 \mathrm{~g} / \mathrm{L} ; \mathrm{NH}_{4} \mathrm{Cl}, 3 \mathrm{~g} / \mathrm{L}$; $\mathrm{MgSO}_{4} 7 \mathrm{H}_{2} \mathrm{O}, 1 \mathrm{~g} / \mathrm{L}$; and amino acids (valine, 0.0502 $\mathrm{g} / \mathrm{L}$; phenylalanine, $0.0132 \mathrm{~g} / \mathrm{L}$; lysine, $0.0184 \mathrm{~g} / \mathrm{L}$; aspartic acid, $0.016 \mathrm{~g} / \mathrm{L}$; serine, $0.0251 \mathrm{~g} / \mathrm{L}$ ). Lysogeny Broth (LB) medium for complex culture and M9 medium for defined medium were used to prepare the seed culture. About $10 \mu \mathrm{L}$ of microorganism was inoculated 
in $10 \mathrm{~mL}$ of sterilized $\mathrm{LB}$ or $\mathrm{M} 9$ and incubated at $37^{\circ} \mathrm{C}$ with shaking at $220 \mathrm{rpm}$ for $12 \mathrm{~h}$.

In all experiments, $10 \%$ of the seed culture was inoculated in a sterile culture medium under the microbial hood and inoculated at $37^{\circ} \mathrm{C}$ with shaking at $220 \mathrm{rpm}$. To investigate the growth curve of E.coli recombinant strain in the complex culture medium, three tests were carried out with different concentrations of glucose $(6$, 9, $12 \mathrm{~g} / \mathrm{L}$ ) as the source of carbon. Recombinant strain was grown in a $250-\mathrm{mL}$ flask containing $100 \mathrm{~mL}$ of culture medium and incubated at $37^{\circ} \mathrm{C}$ with shaking at 220 $\mathrm{rpm}$. The growth of bacteria continued to the end of the growth phase and then IPTG $(0.5 \mathrm{mM})$ was added and cultivation continued for $4 \mathrm{~h}$.

The cell concentration and the protein expression levels were analyzed by optical density and SDS-PAGE, respectively. Sampling was carried out every 1 hour to measure the optical density, dry weight (using an oven at $60^{\circ} \mathrm{C}$ for 24 hours), and protein expression. The amount of expression of $\mathrm{DT}_{389} \mathrm{IL} 2$ was analyzed by SDS-PAGE using the Laemmli method [25].

\section{Cell growth in the bioreactor}

The cell growth of E. coli recombinant strain was studied in a 2-L bioreactor (New Brunswick ${ }^{\mathrm{TM}}$ ) with $1 \mathrm{~L}$ working volume. The cell growth studies have been carried out separately for the complex and defined culture medium in the bioreactor. The composition of medium was selected based on shake-flask culture experiments for both complex and defined mediums for the bioreactor culture. To cultivate recombinant E. coli, the inoculums were first prepared in a $250-\mathrm{mL}$ flask containing $100 \mathrm{~mL}$ of culture medium and were incubated overnight at $37^{\circ}$ $\mathrm{C}$ with shaking at $220 \mathrm{rpm}$.

During the cultivation in the bioreactor, compressed sterile air was sparged into the medium at $1 \mathrm{VVM}$. The agitator was initially set at $250 \mathrm{rpm}$, and during bacterial growth with the increasing optical density of medium, the speed of the stirrer increased (300-550 rpm) and the concentration of dissolved oxygen in the bioreactor has been kept constant. Fermentation parameters such as temperature, $\mathrm{pH}$, dissolved $\mathrm{O}_{2}$, and foaming were continuously monitored and controlled. The sampling was carried out every $1 \mathrm{~h}$ and optical density and biomass production were measured. The induction was carried out with $0.1 \mathrm{mM}$ IPTG at the appropriate optical density.

\section{Results}

Growth of the recombinant strain in a complex culture medium

Figure 1 shows the results of bacteria cultivation in a complex culture medium with different glucose concentrations as the source of carbon in the shake-flask culture.

The optical density was almost the same for all three culture media containing glucose of 6,9 , and $12 \mathrm{~g} / \mathrm{L}$ after $8 \mathrm{~h}$ of cultivation in the shake-flask culture. Analysis of protein expression by SDS-PAGE revealed the highest expression of $\mathrm{DT}_{389} \mathrm{IL} 2$ with a molecular weight of 58 $\mathrm{kDa}$ in the medium containing $6 \mathrm{~g} / \mathrm{L}$ glucose (Figure 2).

Figure 3 shows the optical density and specific growth rate of recombinant E.coli strain BL21 in the complex culture medium containing glucose $6 \mathrm{~g} / \mathrm{L}$ in the bioreac-

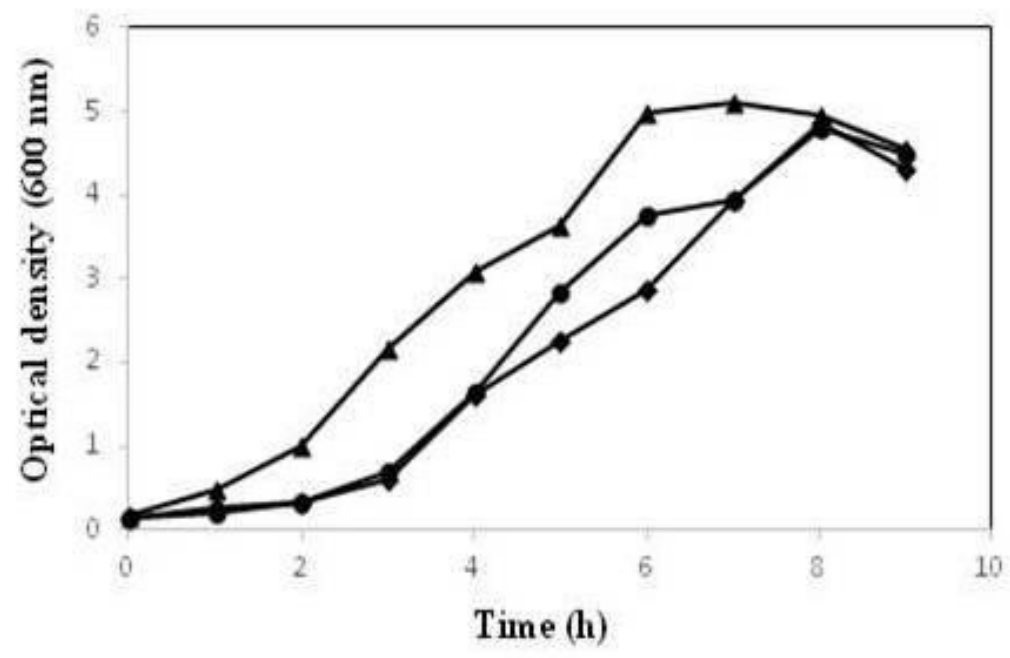

Figure 1. The bacteria growth in the complex culture medium containing glucose of $6(\bullet), 9(\mathbf{\Delta}), 12(\mathbf{\bullet}) \mathrm{g} / \mathrm{L}$ 


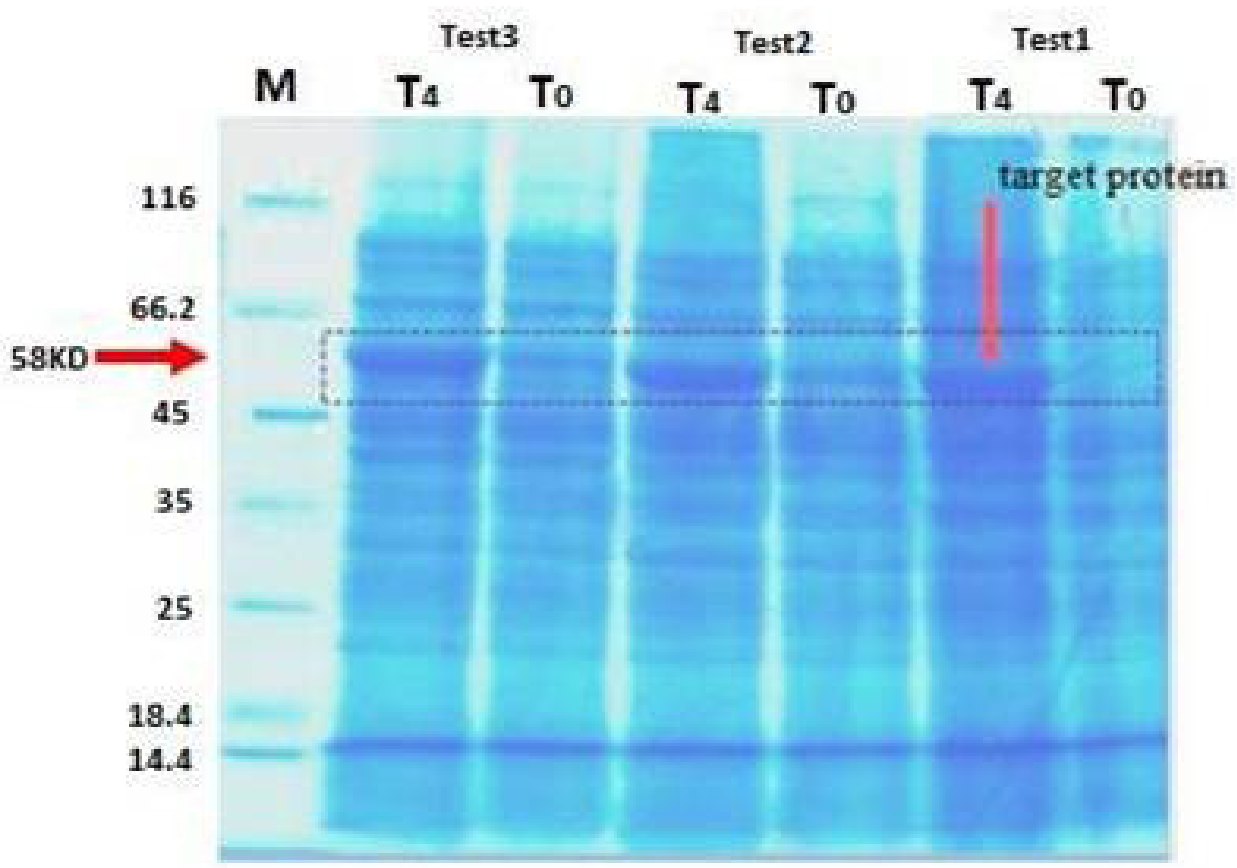

grmm

Figure 2. The expression of DT389IL2 in the complex culture medium on SDS-PAGE.

Test 1: culture medium containing glucose $6 \mathrm{~g} / \mathrm{L}$; Test 2: culture medium containing glucose $9 \mathrm{~g} / \mathrm{L}$; Test 3: culture medium containing glucose $12 \mathrm{~g} / \mathrm{l}, \mathrm{T}_{0}$ : induction time, $\mathrm{T}_{4}: 4 \mathrm{~h}$ after induction

tor culture. The type of culture medium was the most effective factor and complex culture medium associated with glucose of $6 \mathrm{~g} / \mathrm{L}$ was found as the most suitable one on increasing biomass production, and consequently increased the output of the target protein.

Growth of recombinant strain in defined culture medium
Figure 4 shows bacteria growth in the defined culture medium with glucose $8 \mathrm{~g} / \mathrm{L}$ as the carbon source. The results revealed that the optical density of medium increased to 2.95 on batch cultivation in the shake-flask culture. Besides, the amount of expression of $\mathrm{DT}_{389} \mathrm{IL} 2$ was investigated by SDS-PAGE (Figure 5).

The growth of bacteria was investigated in the defined culture medium containing glucose $8 \mathrm{~g} / \mathrm{L}$ in the biore-

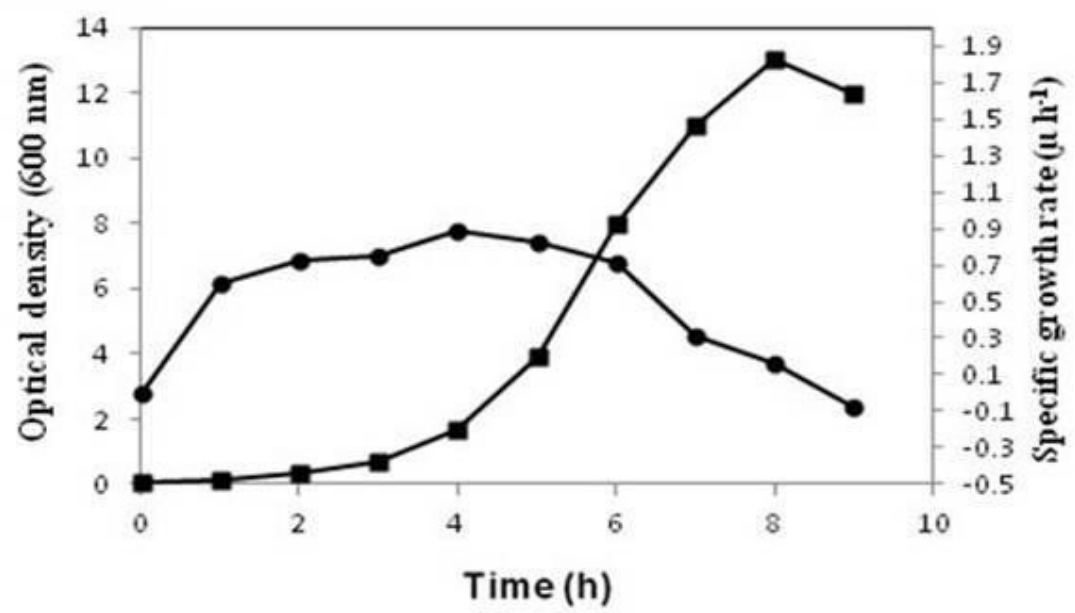

Figure 3. The bacteria growth in the complex culture medium with media containing glucose $6 \mathrm{~g} / \mathrm{L}$ in the bioreactor.

$\bullet ; \mu$ (specific growth rate), $\mathbf{m ; ~ o p t i c a l ~ d e n s i t y . ~}$ 


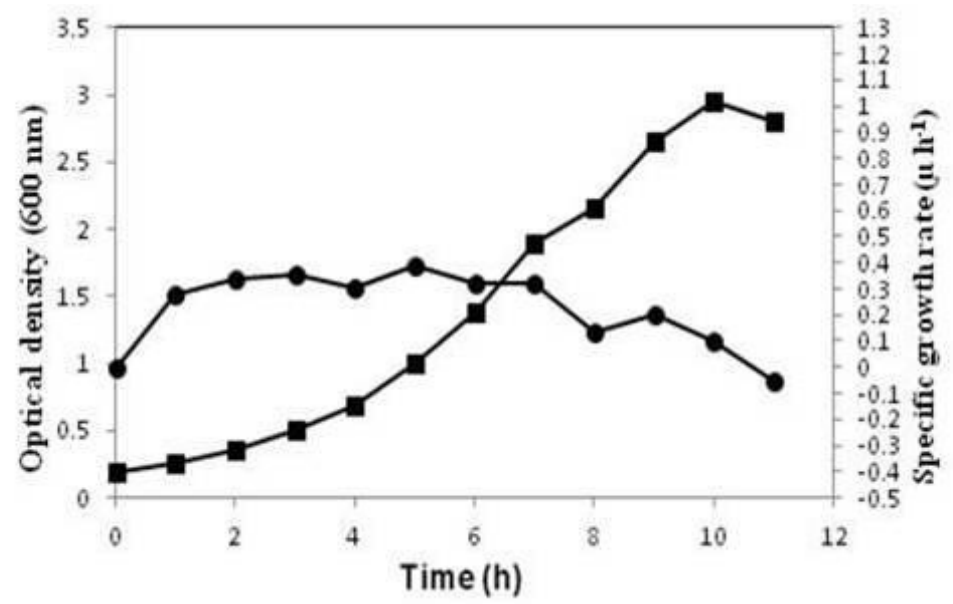

grmm

Figure 4. The bacteria growth in the defined culture medium with media containing glucose $8 \mathrm{~g} / \mathrm{L}$ in the shake-flask culture. -; $\mu$ (specific growth rate), $\mathbf{m}$; optical density.

actor culture (Figure 6). The time of induction was determined in an optical density of 2 and was performed by adding IPTG with a concentration of $0.1 \mathrm{mM}$. The highest production of cells and the expression of target protein in the defined culture medium were determined in the optical density of 6.1 in the bioreactor culture. However, under the same conditions, an optical density of 2.95 was achieved in the shake-flask culture. The results revealed that the maximum specific growth rate of bacteria in the bioreactor was $0.47 \mathrm{~h}^{-1}$ in the defined culture medium.

\section{Discussion}

Toxin-based directed therapy is a subgroup of protein therapies that has been developed over the past several decades. It is also an ideal approach for many investigators in the field of cancer therapy because this treatment minimally affects healthy cells or tissues. In this field, a Japanese company, Eisai, produced and developed the first FDA-approved recombinant immunotoxin, i.e., $\mathrm{DT}_{389} \mathrm{IL} 2$, for the treatment of persistent or recurrent $\mathrm{Cu}-$ taneous T Cell Lymphoma (CTCL) $[15,16]$.

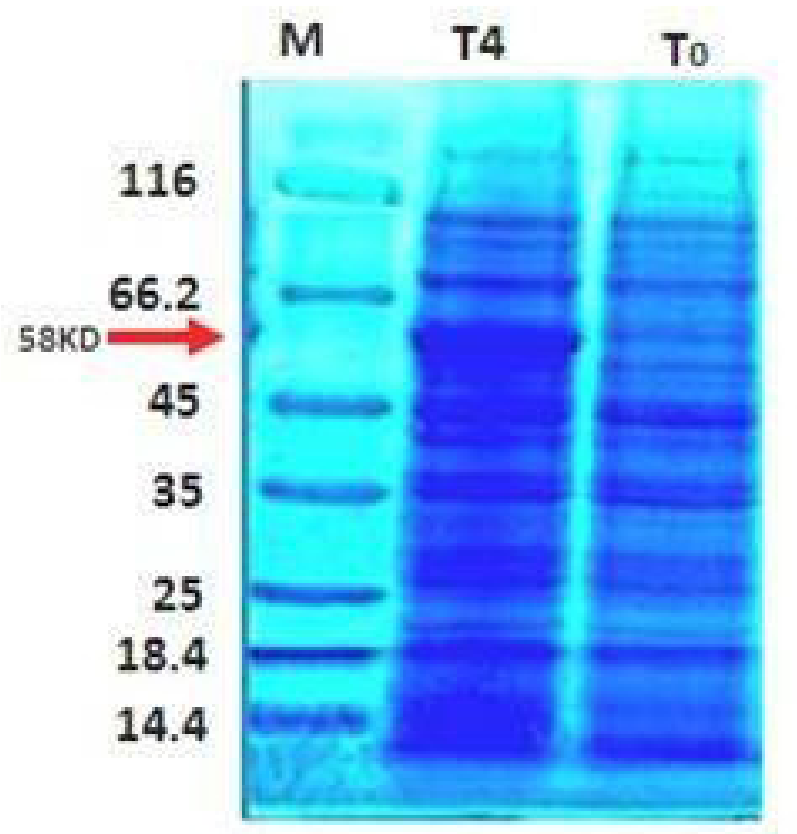

Figure 5. Expression of DT389IL2 in the defined culture medium in the shake-flask culture.

Recombinant bacteria were collected at $0\left(\mathrm{~T}_{0}\right)$ and $4 \mathrm{~h}\left(\mathrm{~T}_{4}\right)$ after induction time. M: protein size marker. 


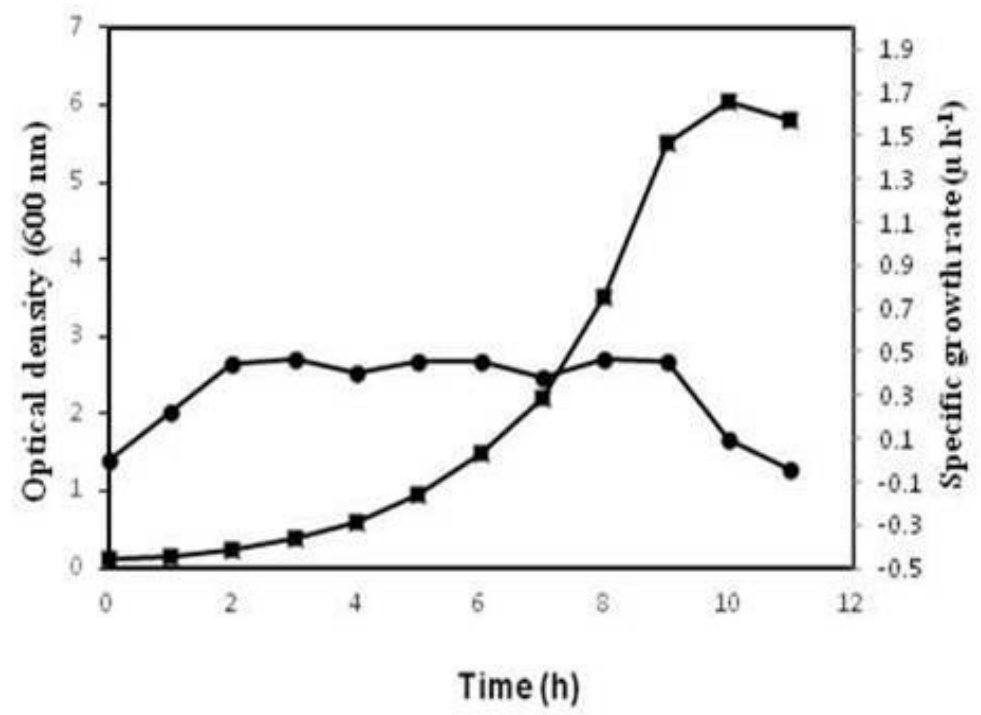

grmm

Figure 6. The bacteria growth in the defined culture medium with carbon sources containing $8 \mathrm{~g} / \mathrm{L}$ glucose in the bioreactor. -; $\mu$ (specific growth rate), $\mathbf{m ;}$ optical density.

On the other hand, the production of recombinant therapeutic proteins in an optimum condition is one of the key problems for drug companies. The use of the best culture medium and optimum condition for fermentation of recombinant protein could be considered for increasing production efficiency. Therefore to extend our previous work that studied the $\mathrm{DT}_{389}$ IL2 expression on E. coli strain on the shake-flask culture with complex culture medium $[21,22]$, we studied on $\mathrm{DT}_{389}$-IL2 production in the lab-scale bioreactor the present work.

The results revealed that the composition and concentration of components of the culture medium had a significant impact on the higher production of $\mathrm{DT}_{389} \mathrm{IL} 2$ by the fermentation process using the E.coli strain. The modified complex culture medium contained glucose, 6 $\mathrm{g} / \mathrm{L} ; \mathrm{K}_{2} \mathrm{HPO}_{4}, 12.5 \mathrm{~g} / \mathrm{L} ; \mathrm{K}_{2} \mathrm{HPO}_{4}, 2.3 \mathrm{~g} / \mathrm{L}$; yeast extract, $20 \mathrm{~g} / \mathrm{L}$; tryptone, $10 \mathrm{~g} / \mathrm{L}$ and showed high growth of cells in the batch culture in the bioreactor. The highest production of cell biomass and expression of target protein were found in an optical density of 13 using the complex culture medium in the bioreactor culture. While under the same conditions, the optical density of 5.5 was achieved in the shake-flask culture $[21,22]$.

Besides, the concentration of produced cell biomass in the bioreactor was determined around $11 \mathrm{~g} / \mathrm{L}$ using the modified complex culture medium. The results revealed that using the modified complex culture medium, the maximum specific growth rate of cells reached 0.89 $\mathrm{h}^{-1}$ in the bioreactor culture and the extent of cell biomass concentration in the bioreactor increased 2.55 times compared to the shake-flask culture. This finding has also been reported in the studies carried out in other studies. Fong et al. could find the best culture medium for the expression of Elastin-Like Polypeptides (ELPs) protein by optimizing the composition of the culture medium [26] In Menderson et al. research for the production of Eg95 protein, the growth of the cells and the expression of the required recombinant protein increased with a change in the composition of culture medium [27]. In this study, the results showed that the use of a complex culture medium containing glucose $6 \mathrm{~g} / \mathrm{L}$ increased the expression of $\mathrm{DT}_{389} \mathrm{IL} 2$ on recombinant E.coli BL21.

The maximum optical density in the flask culture was determined as 2.95 by adding amino acids to the defined culture medium containing glucose, $8 \mathrm{~g} / \mathrm{L} ; \mathrm{K}_{2} \mathrm{HPO}_{4}: 15$ g/L; KH2PO4: 7.5 g/L; acid citric: 2 g/L; $\mathrm{NH}_{4} \mathrm{Cl}: 3 \mathrm{~g} / \mathrm{L}$; and $\mathrm{MgSO}_{4} 7 \mathrm{H}_{2} \mathrm{O}, 1 \mathrm{~g} / \mathrm{L}$. However, under the same condition, the optical density of the fermented medium increased to 6.1 in the bioreactor culture. Adding glucose to the culture medium and its immediate consumption by bacteria led to the fast growth of cells. The results showed that by adding valine, $0.05016 \mathrm{~g} / \mathrm{L}$; phenylalanine, $0.0132 \mathrm{~g} / \mathrm{L}$, lysine, $0.0184 \mathrm{~g} / \mathrm{L}$; aspartic acid, 0.016 $\mathrm{g} / \mathrm{L}$; and serine, $0.0251 \mathrm{~g} / \mathrm{L}$ to the defined culture medium, the expression of target protein $\left(\mathrm{DT}_{389} \mathrm{IL} 2\right)$ increased in recombinant E.coli BL21.

The specific growth rates of bacteria in the complex and the defined culture medium in the bioreactor culture were 0.89 and $0.47 \mathrm{~h}^{-1}$, respectively. Recombinant immunotoxins are currently produced intracellularly by E.coli $[11,22,23,28]$ and extracellularly by yeast or plant $[29$, 30]. In all of these systems, environmental conditions 
and composition of culture medium and cellular requirements have a significant impact on the production of immunotoxins. In the secretary systems, the toxicity of immunotoxin released to the environment negatively affects the rate of production and toxic effects of immunotoxin limits high-cell-density bioreactor production [29]. Therefore, the intracellular production of immunotoxins in the form of the inclusion bodies by cells with high growth rates such as E.coli is still of interest despite its obligatory refolding process. In conclusion, this methodology could be useful for increasing the production yield of this drug protein and other recombinant proteins.

\section{Ethical Considerations}

\section{Compliance with ethical guidelines}

All ethical principles were considered in this article.

\section{Funding}

The authors would like to thank the Department of Bioscience and Biotechnology of Malek Ashtar University of Technology for financial support of this work.

\section{Authors contribution's}

Design, supervision, data analysis, critically revised the manuscript for intellectual content: Seyed Morteza Robatjazi; performing all of the experiments: Sanaz Mahboudi; Data analysis, drafting of the manuscript: Mehdi Zeinoddini; All authors reviewed and approved the final version of the manuscript.

\section{Conflict of interest}

The authors declare no conflict of interest.

\section{References}

[1] Ferlay J, Soerjomataram I, Dikshit R, Eser S, Mathers C, Rebelo $\mathrm{M}$, et al. Cancer incidence and mortality worldwide: Sources, methods and major patterns in GLOBOCAN 2012. Int J Cancer. 2015; 136(5):E359-86. [DOI:10.1002/ijc.29210] [PMID]

[2] Allahyari H, Heidari S, Ghamgosha M, Saffarian P, Amani J. Immunotoxin: A new tool for cancer therapy. Tumor Biol. 2017; 39(2):1-11. [DOI:10.1177/1010428317692226] [PMID]

[3] Narang AS, Desai DS. Anticancer drug development: Unique aspects of pharmaceutical development, In: Narang AS, Desai DS, editors. Pharmaceutical Perspectives of
Cancer Therapeutics. New York: AAPS-Springer Publishing Program; 2009. [DOI:10.1007/978-1-4419-0131-6_2]

[4] Saijo N, Tamura T, Nishio K. Strategy for the development of novel anticancer drugs. Cancer Chemother Pharmacol. 2003; 52(Suppl. 1):S97-S101. [DOI:10.1007/s00280-003-0596-x] [PMID]

[5] Wu HC, Chang DK, Huang CT. Targeted therapy of cancer J Cancer Mol. 2006; 2(2):57-66.

[6] Weiner LM, Surana R, Wang S. Monoclonal antibodies: Versatile platforms for cancer immunotherapy. Nat RevImmunol. 2010; 10(5):317-27. [DOI:10.1038/nri2744] [PMID] [PMCID]

[7] Li YM, Hall WA. Targeted toxins in brain tumor therapy. Toxins. 2010; 2(11):2645-62. [DOI:10.3390/toxins2112645] [PMID] [PMCID]

[8] Adams GP, Weiner LM. Monoclonal antibody therapy of cancer. Nat Biotechnol. 2005; 23(9):1147-57. [DOI:10.1038/ nbt1137] [PMID]

[9] Kreitman, RJ. Immunotoxins for targeted cancer therapy. AAPS J. 2006; 8(3):532-51. [DOI:10.1208/aapsj080363] [PMID] [PMCID]

[10] Frankel AE, Kreitman RJ, Sausville EA. Targeted toxins, Clin Can Res. 2000; 6(2):326-34.

[11] Babavalian E, Zeinoddini M, Saeedinia AR, Mohammadi R, Xodadadi N. Design of a recombinant immunotoxin against the human granulocyte-colony stimulating factor receptor. Mol Biol Rep. 2019; 46(1):1093-7. [DOI:10.1007/s11033-0184567-z] [PMID]

[12] Pastan I, Hassan R, Fitzgerald DJ, Kreitman RJ. Immunotoxin therapy of cancer. Nat Rev Cancer. 2006; 6(7):559-65. [DOI:10.1038/nrc1891] [PMID]

[13] Foss FM. DAB(389)IL-2 (denileukin diftitox, ONTAK): A new fusion protein technology. Clin Lymphoma. 2000; 1(Suppl. 1):S27-31. [DOI:10.3816/CLM.2000.s.005]

[14] Figgitt DP, Lamb HM, Goa KL. Denileukin diftitox. Am J Clin. Dermatol. 2000; 1(1):67-72. [DOI:10.2165/00128071200001010-00008] [PMID]

[15] Eklund JW, Kuzel TM. Denileukin diftitox: A concise clinical review. Expert Rev Anticancer Ther. 2005; 5(1):33-8 [DOI:10.1586/14737140.5.1.33] [PMID]

[16] Kaminetzky D, Hymes KB. Denileukin diftitox for the treatment of cutaneous T-cell lymphoma. Biologics: Targ Thera 2008; 2(4):717-24. [DOI:10.2147/BTT.S3084] [PMID] [PMCID]

[17] Rothen SA, Sauer SB, Witholt B. Growth characteristics of escherichia coli HB101 [Pgec47] on defined medium. Biotech Bioeng. 1998; 58(1):92-100. [DOI:10.1002/(SICI)10970290(19980405)58:13.0.CO;2-7]

[18] Shojaosadati SA, Kolaei SMV, Babaeipour V, Farnoud M Recent advances in high cell density cultivation for production of recombinant protein. Iranian J Biotech. 2008; 6(2):63-8.

[19] Castrillo JI, Kaliterna J, Weusthuis RA, Van JP, Pronk JT High-cell-density cultivations of yeasts on disaccharides in oxygenlimited batch cultures. Biotech Bioeng. 1996;49(6):6218. [DOI:10.1002/(SICI)1097-0290(19960320)49:63.0.CO;2-Q] 
[20] Aristidou AA, San KY, Bennett GN. Modification of central metabolic pathway in escherichia coli to reduce acetate accumulation by heterologous expression of the bacillus subtilis acetolactate synthase gene. Biotech Bioeng. 1994; 44(8):94451. [DOI:10.1002/bit.260440810] [PMID]

[21] Heydari M, Robatjazi SM, Zeinoddini M. [Investigation of the complex culture medium composition for improved production of ONTAK immunotoxin by recombinant Escherichia coli (Persian)]. J Rafsanjan Un Med Sci. 2015; 13(11):1083-90.

[22] Heydari M, Robatjazi SM, Zeinoddini M, Darabi E. [Optimization of chemically defined cell culture media for recombinant ONTAK immunotoxin production (Persian)]. Iran J Med Microbiol. 2014; 8(3):51-7.

[23] Ebrahimi Bagha M, Zeinoddini M, Saeedinia AR, Xodadadi N. Overexpression and purification of diphtheria fusion toxin: DAB389IL-2. J Bionanosci. 2018; 12(5):671-6. [DOI:10.1166/jbns.2018.1575]

[24] Bayat S, Zeinoddini M, Azizi A, Khalili MN. Co-solvents effects on the stability of recombinant immunotoxin denileukin diftitox: Structure and function assessment. Iranian J Sci Tech Transact A: Sci. 2019; 43:1-7. [DOI:10.1007/s40995019-00676-7]

[25] Laemmli UK. Cleavage of structural proteins during the assembly of the head of bacteriophage T4. Nature. 1970; 227(5259):680-5. [DOI:10.1038/227680a0] [PMID]

[26] Fong BA, Wood DW. Expression and purification of ELPintein-tagged target proteins in high cell density E. coli fermentation. Microb Cell Fact. 2010; 9:77. [DOI:10.1186/14752859-9-77] [PMID] [PMCID]

[27] Daniel M, Robert DR, Chisti Y. A recombinant vaccine against hydatidosis: Production of the antigen in Escherichia coli. J Ind Microbiol Biotech. 2006; 33(3):173-82. [DOI:10.1007/s10295-005-0046-3] [PMID]

[28] Donyapoor F, Zeinoddini M, Saeedinia AR. Cloning and expression of recombinant immunotoxin using diphtheria toxin and granulocyte colony stimulating factor (G-CSF). J Arak Un Med Sci. 2016; 19(5):42-50.

[29] Woo JH, Liu YY, Stavrou S, Neville Jr. Increasing secretion of a bivalent Anti-T-Cell immunotoxin by pichia pastoris. Appl Environ Microbiol, 2004; 70(6):3370-6. [DOI:10.1128/ AEM.70.6.3370-3376.2004] [PMID] [PMCID]

[30] Zuppone S, Fabbrini MS, Vago R. Hosts for hostile protein production: The challenge of recombinant immunotoxin expression. Biomedicines, 2019; 7(2):1-17. [DOI:10.3390/biomedicines7020038] [PMID] [PMCID] 